\title{
Evaluation of Cemental Tear Frequency Using Cone-Beam Computed Tomography: A Retrospective Study
}

\author{
Semental Ayrılma Sıklığının Konik Işınlı Bilgisayarlı Tomografi ile \\ Değerlendirilmesi: Retrospektif Bir Çalışma \\ (D) Gökhan Özkan ${ }^{1}$, (1) Hicran Dönmez Özkan²
}

${ }^{1}$ Aydın Adnan Menderes University Faculty of Dentistry, Department of Oral and Maxillofacial Radiology, Aydın, Turkey

${ }^{2}$ Aydın Adnan Menderes University Faculty of Dentistry, Department of Endodontics, Aydın, Turkey

Keywords

Cone-beam computed tomography, prevalence, cemental tear

Anahtar Kelimeler

Konik ışınlı bilgisayarlı tomografi, prevelans, semental ayrılma

Received/Geliş Tarihi : 01.06.2020

Accepted/Kabul Tarihi : 16.06 .2020

doi:10.4274/meandros.galenos.2020.46320

Address for Correspondence/Yazışma Adresi: Gökhan Özkan MD,

Aydın Adnan Menderes University, Faculty

of Dentistry, Department of Oral and

Maxillofacial Radiology, Aydın, Turkey

Phone : +90 5065009470

E-mail : asgokhanozkanus@hotmail.com

ORCID ID: orcid.org/0000-0003-4822-7303

(C) Meandros Medical and Dental Journal, Published by Galenos Publishing House.

This is article distributed under the terms of the

Creative Commons Attribution NonCommercial 4.0

International Licence (CC BY-NC 4.0).

\begin{abstract}
Objective: Cemental tear is a clinical term referring to partial or complete separation of the cementum from the root surface. Unnecessary treatment can be applied due to its low prevalence and difficulty in diagnosis. This study aimed to determine the frequency and distribution of cemental tear using cone-beam computed tomography (CBCT).

Materials and Methods: A total of 813 CBCT images were evaluated in this retrospective study. Root fragments that were separated from the root surface on CBCT images were accepted as cemental tear. The frequency of cemental tear, tooth region, tooth type, previous treatment and periapical/periodontal lesions were assessed. A chi-square test was performed to determine the relationship between the categorical variables.

Results: The frequency of cemental tear was determined to be $1.85 \%$. Of the patients, $51.3 \%$ were males $(n=417)$ and $48.7 \%(n=396)$ were females. There was no significant relationship between the frequency of cemental tear and patient age, gender, tooth region, tooth type and previous treatment ( $p>0.05)$. In teeth with periapical/periodontal lesions, significantly more frequent cemental tears were observed $(p<0.05)$.

Conclusion: Early diagnosis is essential to prevent advanced bone loss and extraction of teeth with cemental tear. Clinicians may misdiagnose teeth with cemental tears without adequately evaluating all predisposing factors, clinical features and available radiographs. Further studies with larger sample sizes could be useful to more precisely determine the predisposing factors and clinical features of cemental tear.
\end{abstract}

Öz

Amaç: Semental ayrılma, sementin kök yüzeyinden tamamen veya kısmen ayrılması anlamına gelen klinik bir terimdir. Düşük prevalansı ve teşhis zorluğu nedeniyle gereksiz tedavi uygulanabilmektedir. Bu çalışmada, semental ayrılma sıkığı ve dağılımının konik ışınlı bilgisayarlı tomografi (KIBT) kullanılarak belirlenmesi hedeflenmiştir.

Gereç ve Yöntemler: Toplam 813 KIBT görüntüsü bu retrospektif çalışmada değerlendirildi. KIBT görüntüleri üzerinde, kök yüzeyinden ayrılmış kök parçaları 
semental ayrılma olarak kabul edildi. Semental ayrılma sıklığı, diş bölgesi, diş tipi, önceden uygulanan tedaviler ve periapikal/ periodontal lezyon varlığı değerlendirildi. Kategorik değişkenler arasındaki ilişkiyi belirlemek için ki-kare testi kullanıldı.

Bulgular: Semental ayrılma sıklı̆ı \%1,85 olarak belirlendi. Hastaların \%51,3'ü erkek (n=417) ve \%48,7'si $(n=396)$ kadındı. Semental ayrılma sıklığı ile hasta yaşı, cinsiyeti, diş bölgesi, diş tipi ve önceki tedavi arasında anlamlı bir ilişki saptanmadı $(p>0,05)$. Periapikal/ periodontal lezyonlu dişlerde anlamlı olarak daha fazla semental ayrılma gözlendi $(p<0,05)$.

Sonuç: Semental ayrılma bulunan dişlerde ileri kemik kaybını ve dişin çekimini önleyebilmek için erken teşhis çok önemlidir. Klinisyenler tüm predispozan faktörleri, klinik özellikleri ve mevcut radyografları yeterince değerlendirmeden semental ayrılma bulunan dişlere yanlış tanı koyabilirler. Semental ayrılmanın predispozan faktörlerini ve klinik özelliklerini kesin olarak belirleyebilmek için daha büyük örneklem büyüklüğü ile yapılacak ileri çalışmalar yararlı olabilir.

\section{Introduction}

Cemental tear is a clinical term that refers to complete or partial separation of the cementum from the root surface along the cementodentinal interface or incremental line (1). Although the exact cause of cemental tear is not fully clear, it has been associated in the literature with increased age, traumatic occlusion, trauma, previous periodontal treatment, and previous root canal treatment $(2,3)$. It has been reported that cemental tear can be confused with an endodontic or periodontal lesion and can lead to advanced bone loss if left untreated (3). Additionally, cemental tear can be confused with vertical root fracture (VRF) in endodontically treated teeth. Both pathologies are characterized by deep or isolated periodontal pockets, periodontal or periapical bone loss, gingival abscess, and the presence of a sinus tract (3-5). However, while VRF is frequently observed in endodontically treated teeth and more frequently in molars, cemental tear is observed in both vital and endodontically treated teeth and, more frequently, in the anterior teeth. In addition, while VRF is observed more frequently in the bucco-lingual direction, cemental tear is frequently observed on proximal surfaces (4-8). When a cemental tear is diagnosed accurately, it can be treated by removing the fractured part through periodontal curettage and root planning, periodontal surgery, and/or apical surgery (9). In addition, its low prevalence reduces the likelihood of noticing and diagnosing a cemental tear $(3,5)$. In the literature, it is reported that cemental tear is often misdiagnosed, and root canal treatment is applied to the teeth due to the clinical features of cemental tear mimicking periodontal and periapical lesions $(6,7)$. It is reported that cemental tear causes an increase in existing periodontal and periapical bone destruction when left untreated or when improperly treated $(8,9)$. Therefore, accurate diagnosis of cemental tear is critical in the prognosis of the affected tooth (10). A definitive diagnosis of cemental tear can be made by histopathological examination of the removed fragment (9). However, studies and case reports in the literature show that prevalence was determined by periapical and panoramic radiographs $(10,11)$. Despite the fact that the presence of a thin radiopaque fragment on the root surface suggests cemental tear on radiograph, it is difficult to make an accurate diagnosis with two-dimensional imaging $(5,10)$. Although cone-beam computed tomography (CBCT) is recommended in the literature (11) to screen cemental tear, there is no research on this subject. Therefore, the purpose of this study is to determine the frequency of cemental tear using CBCT images of patients who were admitted to a University Dental Hospital in the Aegean region of Turkey over a period of one year and to evaluate the relationship of cemental tear with the gender, age, tooth type, and previous treatments of the patients.

\section{Materials and Methods}

Aydın Adnan Menderes University Clinical Research Ethics Committee approved this study (protocol number: ADUDHF 2019/074, date: 20.11.2019). CBCT images (Planmeca Promax 3D Mid, Helsinki, Finland) of patients who applied to our faculty's Oral and Maxillofacial Radiology Department between January 2015 and January 2019 were used in the study. Images that do not include both jaws or have poor image quality were excluded. A total of 813 CBCT images were evaluated retrospectively. Patient consent was not obtained due to the retrospective evaluation of CBCT images.

In addition to age and gender information for the patients, previous treatment experiences were obtained from the patient records. Groups were classified as aged 18-39 years, 40-59 years, and 60 
years and over. Images of patients younger than 18 years old were not included in the study. The presence or absence of cemental tear in all teeth was determined through CBCT images. Root fragments that were completely or partially separated from the root surface were considered to be cemental tears (Figure 1). The frequency, mesiodistal location (buccal/labial, palatal/lingual, or proximal) and apicocoronal location (cervical one-third, middle one-third, or apical onethird) of the cemental tear as well as tooth region (maxilla or mandible), tooth type (incisor, premolar, or molar), presence or absence of previous treatment, and periapical/periodontal lesions were evaluated by an experienced oral radiologist. Evaluations were repeated by the same examiner two weeks later.

\section{Statistical Analysis}

Data were analyzed using the statistical software package SPSS v25.0 (IBM Corp., Armonk, NY). Descriptive statistics and frequency tables were used to evaluate the data. To determine the relationship between categorical variables, chi-square tests were performed. $\mathrm{P}<0.05$ was considered statistically significant. The intra-examiner agreement was evaluated using the Kappa coefficient.

\section{Results}

In this study, 15,886 teeth of 813 patients were evaluated, and $1.85 \%(n=15)$ of the patients were diagnosed with cemental tear. The intraexaminer agreement for CBCT evaluations was 0.92, demonstrating almost perfect agreement. Of the patients, $51.3 \%$ were male $(n=417)$, and $48.7 \%$ $(n=396)$ were female; $53.3 \%$ of the patients in whom cemental tear was detected were male $(n=8)$, and $46.7 \%$ were female $(n=7)$. There was no statistically significant difference between the genders in terms of cemental tear occurrence $(p>0.05)$. The average age of the 15 patients with cemental tears was

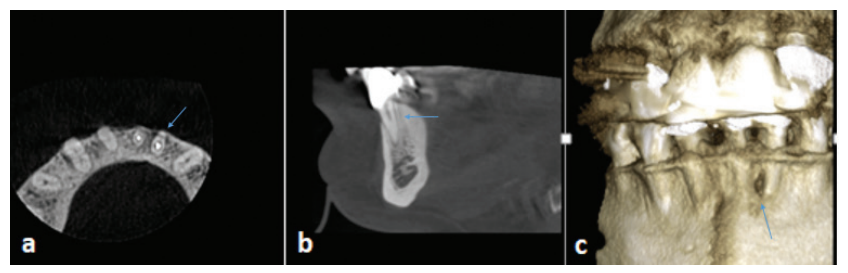

Figure 1. Axial (a), sagittal (b), and three-dimensional reconstruction (c) views of cemental tear cases on $\mathrm{CBCT}$

CBCT: Cone-beam computed tomography
$49.20 \pm 16.4$ years. The age group with the greatest number of cemental tears was 18 -39 years (40.3\%); however, no statistically significant difference was found between age and the occurrence of cemental tear ( $p>0.05)$. Of the teeth with cemental tear, 53.3\% were detected in the maxillary region $(n=8)$, and $46.7 \%$ were detected in the mandibular region $(n=7)$. The demographic and clinical features of the patients are provided in Table 1. A statistical analysis revealed that there was no significant difference between the maxillary and mandibular region in terms of cemental tear occurrence $(p>0.05)$. The teeth more frequently affected by cemental tear were incisors (53.3\%). However, the effect of tooth type on cemental tear was not statistically significant $(p>0.05)$. Prosthetic restoration was detected in $33.3 \%$ of the teeth with cemental tear $(n=5)$; however, the presence or absence of prosthetic restorations had no statistically significant effect on cemental tear $(p>0.05)$. No previous root canal treatment was observed in 11 of the 15 teeth with cemental tear; however, no statistically significant effect was detected in the presence or absence of previous root canal treatment on cemental tear $(p>0.05)$. In 12 of the 15 cases, periapical/periodontal bone loss was detected; the presence of periapical/periodontal bone loss had a statistically significant effect on cemental tear $(p<0.05)$. Proximal surfaces were the most frequently observed direction detected with cemental tear. There was a statistically significant difference in the occurrence of cemental tear only between proximal surfaces and lingual surfaces $(p<0.05)$. There was no statistical difference between apicocoronal locations $(p>0.05)$. No patients with multiple cemental tears were observed. The clinical and radiological characteristics of cemental tear cases are provided in Table 2.

\section{Discussion}

Due to its low frequency, cemental tear can be confused with other endodontic and periodontal lesions $(3,12)$. Little information is found in the literature about the frequency of cemental tear. In the present study, the frequency of cemental tear was found to be $1.85 \%$. Keskin and Güler (10) reported a frequency of $0.89 \%$ for cemental tear in their study, which was performed in a different region of Turkey. These different findings may be the result of 


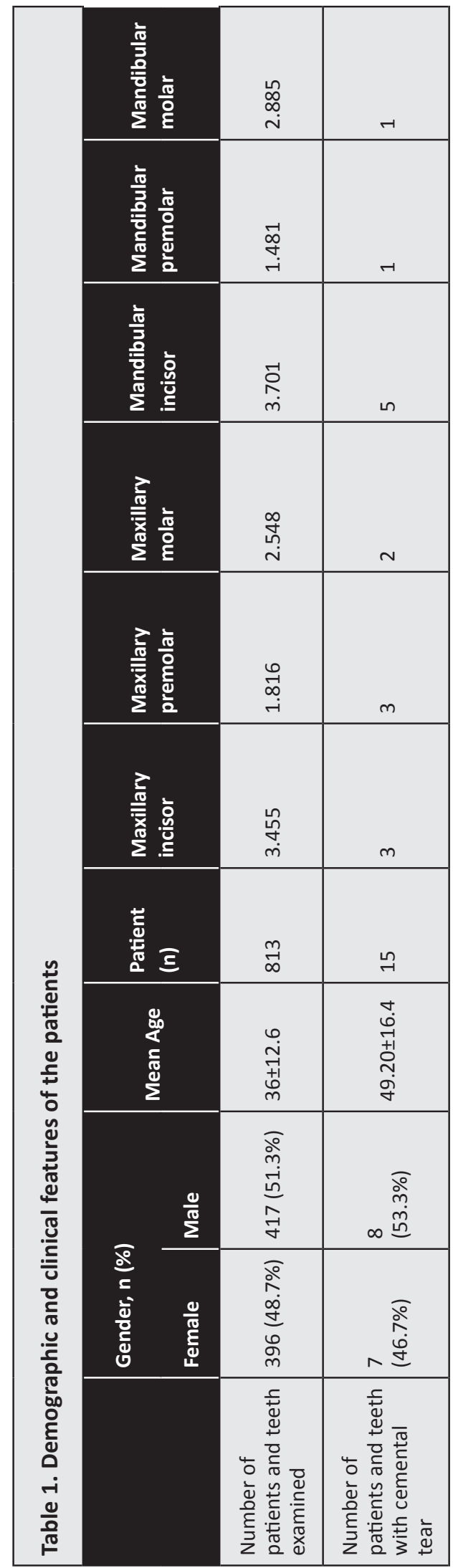

differences in the radiological methods used and in the populations involved in the studies. In the literature, the use of CBCT is recommended to diagnose cemental tear instead of two-dimensional imaging in order to differentiate cemental tear from endodontic/ periodontal lesions $(11,13)$. Two-dimensional imaging cannot diagnose cemental tears in the buccal/labial or lingual/palatal directions of the teeth (10).

No gender or age predilection was observed in the present study in terms of cemental tear occurrence, similar to the report by Keskin and Güler (10). In two different studies, Lin et al. $(3,5)$ reported that cemental tear is more common in men and in patients older than 60 years. In addition, the results of the present study revealed that clinical characteristics and conditions of the teeth such as tooth region, tooth type, presence of prosthetic restoration, and previous root canal treatment did not affect the occurrence of cemental tear. Only the presence of periapical/periodontal bone loss was found to be related to the formation of cemental tear, similar to the findings of Lin et al. (3) and Keskin and

Table 2. Clinical and radiological characteristics of cemental tear cases

\begin{tabular}{|c|c|c|}
\hline CBCT examination & $\begin{array}{l}\text { Analyzed } \\
\text { sample }\end{array}$ & p \\
\hline \multicolumn{2}{|c|}{ Prosthetic restoration } & \multirow{3}{*}{$p>0.05$} \\
\hline Yes & 5 & \\
\hline No & 10 & \\
\hline \multicolumn{2}{|c|}{ Previous root canal treatment } & \multirow{3}{*}{$p>0.05$} \\
\hline Yes & 4 & \\
\hline No & 11 & \\
\hline \multicolumn{2}{|c|}{ Periapical/periodontal bone loss } & \multirow{3}{*}{$p<0.05$} \\
\hline Yes & 12 & \\
\hline No & 3 & \\
\hline \multicolumn{2}{|c|}{ Mesiodistal direction } & \multirow{4}{*}{$p<0.05$} \\
\hline Proximal $^{a}$ & 9 & \\
\hline Lingual ${ }^{b}$ & 2 & \\
\hline Buccal ${ }^{\mathrm{ab}}$ & 4 & \\
\hline \multicolumn{2}{|c|}{ Apicocoronal location } & \multirow{4}{*}{$p>0.05$} \\
\hline Cervical one-third & 3 & \\
\hline Middle one-third & 4 & \\
\hline Apical one-third & 8 & \\
\hline
\end{tabular}


Güler (10). On the other hand, both of these studies $(3,10)$ suggested that the presence of cemental tear is more common in the maxillary region. While Lin et al. (3) declared that the type of teeth is important in the formation of cemental tear, Keskin and Güler (10) reported that it is not. In the present study, most of the cemental tears were detected in the proximal root surfaces, which is similar to the findings of Lin et al. (5). However, while the most common location was the middle one-third in their study, in our study, the most common location was in the apical onethird. It is thought that these differences may be due to the different study populations, study designs, and the sample sizes of the researches.

No patient with multiple cemental tear was detected in this study. There are few case reports in the literature of multiple cemental tears in a single patient $(6,11,12)$. Watanabe et al. (12) declared that multiple cemental tears may result from the structural weakness of the cementum.

In this retrospective study, СВCT images were used to detect cemental tears. Thanks to the use of three-dimensional imaging, the limitations of two-dimensional imaging were eliminated. CBCT images can detect the location of cemental tears and positively affect treatment outcomes (11). Although CBCT offers high resolution three-dimensional imaging, the exact diagnosis of cemental tear can be made only by histopathological examination of the removed fragment $(3,5,9,13)$. Since this study was retrospective, histopathological examination was not performed, and the possible causes of cemental tear, such as occlusion disorders, trauma, and bruxism, could not be evaluated. In addition, the treatment interventions for all teeth with cemental tear were not available in the patient records.

The prognosis of untreated or improperly treated teeth with cemental tear will inevitably become worse because of increasing periodontal and periapical bone destruction. Several treatment options exist for cemental tear, including periodontal treatment, root canal treatment, apical surgery, and tooth extraction (9-16). Appropriate treatment can vary depending on whether the cemental tear is diagnosed early or late as well as according to clinical or radiological signs. Lin et al. (5) emphasized that cemental tear should be completely removed to improve prognosis. Watanabe et al. (12) recommended the management of occlusion to prevent recurrence if the main cause is occlusal trauma. The authors recommended the extraction of the tooth in the case of a structural defect, which can lead to recurrence. Chou et al. (14) suggested periodontal surgery and a proper maintenance regimen for the treatment of a tooth with cemental tear. Pilloni et al. (15) reported that after removal of the cemental tear, the teeth can be successfully treated using hyaluronic acid and an absorbable collagen membrane. Qari et al. (16) declared that local, conservative curettage is the best treatment approach in cases in which periodontal probing is negative, tooth vitality is positive, and the lamina dura is destroyed. Lin et al. (9) reported that most teeth with cemental tears can maintain their function in the mouth with nonsurgical and surgical periodontal and endodontic interventions.

\section{Conclusion}

Cemental tear may occur in association with various predisposing factors reported in the literature. In the present study, only periapical/periodontal bone loss contributed to the formation of cemental tear. The frequency of cemental tear was determined to be $1.85 \%$. Due to its rare occurrence, early and accurate diagnosis of the lesion is crucial to ensure a successful treatment approach. A prospective study conducted with a larger sample size and including histopathological examination of the removed fragment will be more decisive in determining the frequency and characteristics of cemental tear.

\section{Ethics}

Ethics Committee Approval: Aydın Adnan Menderes University Clinical Research Ethics Committee approved this study (protocol number: ADUDHF 2019/074, date: 20.11.2019).

Informed Consent: Patient consent was not obtained due to the retrospective evaluation of CBCT images.

Peer-review: Externally peer-reviwed.

\section{Authorship Contributions}

Concept: G.Ö., H.D.Ö., Design: G.Ö., H.D.Ö., Supervision: G.Ö., Data Collection or Processing: G.Ö., Analysis or Interpretation: H.D.Ö., Materials: G.Ö., Literature Search: G.Ö., H.D.Ö., Writing: G.Ö., H.D.Ö. 
Conflict of Interest: No conflict of interest was declared by the authors.

Financial Disclosure: The authors declared that this study received no financial support.

\section{References}

1. Haney JM, Leknes KN, Lie T, Selving KA, Wikesjo UM. Cemental tear related to rapid periodontal breakdown: a case report. J Periodontol 1992; 63: 220-4.

2. Leknes KN, Lie T, Selvig KA. Cemental tear: a risk factor in periodontal attachment loss. J Peridontol 1996; 67: 583-8.

3. Lin HJ, Chan CP, Yang CY, Wu CT, Tsai YL, Huang CC, et al. Cemental tear:clinical characteristics and its predisposing factors. J Endod 2011; 37: 611-8.

4. Moule AJ, Kahler B. Diagnosis and management of teeth with vertical root fractures. Aust Dent J 1999; 44: 75-87.

5. Lin HJ, Chang MC, Chang $\mathrm{SH}$, Wu CT, Tsai $\mathrm{YL}$, Chiang CP, et al. Clinical fracture site, morphology and histopathologic characteristics of cemental tear: role in endodontics lesion. J Endod 2012; 38: 1058-62.

6. Tai TF, Chiang CP, Lin CP, Lin CC, Jeng JH. Persistent endodontic lesion due to complex cemento dentinal tears in a maxillary central incisor: a case report. Oral Surg Oral Med Oral Pathol Oral Radiol Endod 2007; 103: e55-60.

7. Camargo PM, Pirih FQ, Wolinsky LE, Lekovic V, Kamrath H, White SN. Clinical repair of an osseous defect associated with a cemental tear: a case report. Int J Periodontics Restorative Dent 2003; 23: 79-85.
8. Jeng PY, Luzi AL, Pitarch RM, Chang MC, Wu YH, Jeng JH. Cemental tear: To know what we have neglected in dental practice. J Formos Med Assoc 2018; 117: 261-7.

9. Lin HJ, Cheng MC, Chang SH, Wu CT, Tsai YL, Huang CC, et al. Treatment outcome of the teeth with cemental tears. J Endod 2014; 40: 1315-20.

10. Keskin C, Güler DH. A retrospective study of the prevalence of cemental tear in sample of the adult population applied Ondokuz Mayıs University Faculty of Dentistry. Meandros Med Dent J 2017; 18: 115-9.

11. Ong TK, Harun N, Lim TW. Cemental tear on maxillary anterior incisors: A description of clinical, radiographic, and histopathological features of two clinical cases. Eur Endod J 2019; 4: 90-5.

12. Watanabe C, Watanabe $Y$, Miyauchi M, Fujita M, Watanabe Y. Multiple cemental tears. Oral Surg Oral Med Oral Pathol Oral Radiol 2012; 114: 365-72.

13. Tulkki MJ, Baisden MK, McClanahan SB. Cemental tear: a case report of a rare root fracture. J Endod 2006; 32: 1005-7.

14. Chou J, Rawal YB, O'Neil JR, Tatakis DN. Cementodentinal tear: acase report with 7-year follow-up. J Periodontol 2004; 75: 1708-13.

15. Pilloni A, Nardo F, Rojas MA. Surgical Treatment of a Cemental Tear-Associated Bony Defect Using Hyaluronic Acid and a Resorbable Collagen Membrane: A 2-YearFollow-Up. Clin Adv Periodontics 2019; 9: 64-9.

16. Qari H, Dorn SO, Blum GN, Bouquot JE. The pararadicular radiolucency with vital pulp: Clinicopathologic features of 21 cemental tears. Oral Surg Oral Med Oral Pathol Oral Radiol 2019; 128: 680-9. 